\title{
Molecular basis of hypohidrotic ectodermal dysplasia: an update
}

\author{
Wieslaw H. Trzeciak ${ }^{1} \cdot$ Ryszard Koczorowski $^{2}$
}

Received: 12 June 2015 /Revised: 15 July 2015 / Accepted: 19 July 2015 /Published online: 21 August 2015

(C) The Author(s) 2015. This article is published with open access at Springerlink.com

\begin{abstract}
Recent advances in understanding the molecular events underlying hypohidrotic ectodermal dysplasia (HED) caused by mutations of the genes encoding proteins of the tumor necrosis factor $\alpha(\mathrm{TNF} \alpha)$-related signaling pathway have been presented. These proteins are involved in signal transduction from ectoderm to mesenchyme during development of the fetus and are indispensable for the differentiation of ectoderm-derived structures such as eccrine sweat glands, teeth, hair, skin, and/or nails. Novel data were reviewed and discussed on the structure and functions of the components of $\mathrm{TNF} \alpha$-related signaling pathway, the consequences of mutations of the genes encoding these proteins, and the prospect for further investigations, which might elucidate the origin of HED.
\end{abstract}

Keywords Differentiation of skin appendages $\cdot$ Hypohidrotic ectodermal dysplasia $\cdot \mathrm{TNF} \alpha$-related signaling pathway

\section{Introduction}

Ectodermal dysplasias comprise a large group of congenital developmental disorders of at least two ectoderm-derived

Communicated by: Michal Witt

Wieslaw H. Trzeciak

trzeciak@ump.edu.pl

1 Department of Biochemistry and Molecular Biology, Poznan University of Medical Sciences, 6, Swiecickiego St., 60-781 Poznan, Poland

2 Department of Gerostomatology, Poznan University of Medical Sciences, 6, Swiecickiego St., 60-781 Poznan, Poland structures: eccrine sweat glands, teeth, hair, skin, and/or nails. Out of over 170 types of dysplasia (Pinheiro and Freire-Maia 1994; Priolo and Lagana 2001) the most common is ectodermal dysplasia 1 (OMIM 305100), an X-linked hypohidrotic form (HED), which occurs in the general population with a frequency of one per 17,000 live births.

HED embraces a genetically heterogeneous group of diseases and is due to mutations of several genes that encode components of the tumor necrosis factor $\alpha(\mathrm{TNF} \alpha)$-related signaling pathway (Cluzeau et al. 2011). Mutations of these genes disturb the interaction, which takes place during embryonic development, between surface-located epithelial cells and the underlying mesenchyme (Schmidt-Ullrich and Paus 2005). In consequence, the process of initiation, formation, and differentiation of skin appendages is disturbed.

It has been demonstrated that HED is caused by mutations of several genes: $E D 1$, encoding a ligand-ectodysplasinA-A1 (EDA-A1), EDAR, coding for ectodysplasinA-A1 receptor, $E D A R A D D$, programming the structure of EDAR-associated death domain protein and $N E M O$ whose protein product, $\mathrm{NF} \kappa \mathrm{B}$ essential modulator (NEMO), is necessary for an indirect activation of nuclear factor $\mathrm{KB}(\mathrm{NF} \kappa \mathrm{B})$. With the exception of EDA1 and NEMO, both localized on the $\mathrm{X}$ chromosome, all other genes encoding components of the TNF $\alpha$ related signaling pathway involved in differentiation of skin appendages, are localized on the autosomes (Table 1).

Within the last 10 years significant progress has been made in understanding the pathogenesis of HED and this is mainly due to the discovery of unknown proteins and the elucidation of their function in signal transduction via the TNF $\alpha$-related pathway.

The purpose of this report is to review current literature on the structure and function of components of the TNF $\alpha$-related signaling pathway, to present a novel approach to their contribution in the differentiation of skin appendages and to discuss 
Table 1 Mutation of genes encoding proteins involved in TNF $\alpha$-related signal transduction pathway

\begin{tabular}{|c|c|c|c|c|c|c|c|c|c|c|c|}
\hline \multirow[t]{2}{*}{ Protein } & \multirow[t]{2}{*}{ Gene } & \multirow{2}{*}{$\begin{array}{l}\text { Cytogenetic } \\
\text { location }\end{array}$} & \multirow{2}{*}{$\begin{array}{l}\text { OMIM } \\
\text { number* }\end{array}$} & \multicolumn{7}{|c|}{ Main types of mutation* } & \multirow[t]{2}{*}{ Total } \\
\hline & & & & $\begin{array}{l}\text { Missense/ } \\
\text { nonsense }\end{array}$ & $\begin{array}{l}\text { Splicing } \\
\text { defect }\end{array}$ & $\begin{array}{l}\text { Small } \\
\text { deletion }\end{array}$ & $\begin{array}{l}\text { Small } \\
\text { insertion }\end{array}$ & $\begin{array}{l}\text { Small } \\
\text { in/del }\end{array}$ & $\begin{array}{l}\text { Gross } \\
\text { deletion }\end{array}$ & $\begin{array}{l}\text { Gross } \\
\text { in/del }\end{array}$ & \\
\hline Ectodysplasin A1 & $E D A$ & Xq12-q13.1 & 305100 & 117 & 20 & 33 & 12 & 2 & 21 & 1 & 206 \\
\hline Ectodysplasin A1 receptor & $\begin{array}{l}E D A 1 R \\
\quad(E D A R)\end{array}$ & 2q 12.3 & 129490d 224900r & 25 & 5 & 6 & 2 & 1 & 2 & - & 41 \\
\hline $\begin{array}{l}\text { Ectodysplasin A2 receptor } \\
\text { (XEDAR) }\end{array}$ & $\begin{array}{l}E D A 2 R \\
\quad(X E D A R)\end{array}$ & $\mathrm{Xq} 12$ & - & - & - & - & - & - & - & 1 & 1 \\
\hline $\begin{array}{l}\text { EDAR-associated death } \\
\text { domain }\end{array}$ & EDARADD & $1 \mathrm{q} 43$ & 606603 & 5 & - & 1 & - & - & - & - & 6 \\
\hline NF-kB essential modulator & NEMO & $\mathrm{Xq} 28$ & 300291 & 44 & 6 & 21 & 15 & - & 2 & 2 & 90 \\
\hline $\begin{array}{l}\text { TNF receptor-associated } \\
\text { factor } 6\end{array}$ & TRAF6 & $11 \mathrm{p} 12$ & - & - & - & 1 & - & - & - & - & 1 \\
\hline
\end{tabular}

*OMIM number designates disease **In/del, insertions/deletions; d, dominant; r, recessive

the role of mutations of genes encoding components of this pathway in the origin of HED.

Mutations of these genes are responsible for systemic tooth agenesis, in addition to the defects of other ectodermal structures, and this review is limited to description of the function of their protein products.

The molecular basis of non-syndromic tooth agenesis, which is caused by mutations of other genes mainly WNT10A, (Arte et al. 2013; He et al. 2013; van den Boogaard et al. 2012) but also MSXI (Wang et al. 2011) and PAX9, ( Paixao-Cortes et al. 2011) will not be discussed, because it was thoroughly reviewed by several authors (Kapadia et al. 2007; Mostowska et al. 2003; Yin and Bian 2015).

\section{Signal transduction from ectoderm to mesenchyme through the TNF $\alpha$-related pathway}

The signaling via the TNF $\alpha$-related pathway, which is critical for differentiation of skin appendages, has been elucidated mainly due to the investigations performed in mice (Mikkola 2009). It is initiated by one of the Wnt (wingless-type MMTV integration site) family of ligands (Rao and Kuhl 2010) probably WNT10A (Adaimy et al. 2007; Nawaz et al. 2009), which activates receptors belonging to the frizzled (Dann et al. 2001) and LRP (LDL receptor-related protein) (May et al. 2007) families. The downstream signal transduction toward Eda-A1 involves the canonical Wnt/ $\beta$-catenin pathway (Clevers 2006) and requires lymphoid enhancer-binding factor-1 (Lef-1) for activation of the $E d 1$ ( $T a$ ) expression (Durmowicz et al. 2002). In addition to its role in regulating $E d 1$ expression, the $\mathrm{Wnt} / \beta$-catenin pathway also regulates expression of Edar (Laurikkala et al. 2002).

Murine Eda-A1 (Srivastava et al. 1997), encoded by the Ta (Tabby) gene (Srivastava et al. 1997), contains 391 amino acids and its two amino acids shorter isoform, Eda-A2 encoded by the same gene (Yan et al. 2000) belong to the $\mathrm{TNF} \alpha$ family of ligands and are involved in epithelialmesenchymal interactions (Ezer et al. 1999; Mikkola and Thesleff 2003). They are transmembrane type II proteins with the C-terminus projecting outward (Ferguson et al. 1997; Kere et al. 1996; Monreal et al. 1998). Human EDA-A1 and EDAA2 contain the same number of amino acids as their murine orthologues, and their structure is highly homologous to murine proteins. The C-terminal sequence of EDA-A1 and EDAA2 (last 62 or 60 amino acids, respectively) is highly homologous to the C-terminal sequence of $\mathrm{TNF} \alpha$ receptor ligands and forms a triple helix with the same sequences of two other identical molecules. The trimeric EDA-A1 (or EDA-A2) are stabilized by disulfide bonds formed by cysteine residues (Ezer et al. 1999).

The triple helix can be formed because the C-terminal domain (130 or 128 amino acids respectively) contains two clusters of collagen-like Gly-X-Y repeats (4 and 23 respectively). Near the shorter cluster there is an amino acid sequence: ArgVal-Arg-Arg156-Asn-Lys-Arg representing overlapping consensus cleavage sites (Arg-X-Lys/Arg-Arg) recognized by furin-related protease that converts the $\mathrm{C}$-terminal domain into a free ligand (Elomaa et al. 2001). Missense mutations, which occur most frequently at Arg156, account for approximately $20 \%$ of HED cases (Chen et al. 2001; Elomaa et al. 2001).

The binding sites for the two ligands are located in the Nterminal domains of different receptors. The Edar1(Edar) binds only Eda-A1 while another receptor, Edar2 (named Xedar), binds exclusively Eda-A2 (Bayes et al. 1998; Yan et al. 2000).

Both Edar and Xedar are transmembrane proteins composed of an N-terminal, extracellular domain, a single transmembrane domain, and a $\mathrm{C}$-terminal, intracellular region (Headon and Overbeek 1999).

Murine Edar, encoded by the $d l$ (downless) gene, and its human orthologue, EDAR, encoded by the EDAR gene, 
belong to the family of the TNF receptors. Human EDAR contains 448 amino acids and exhibits $91 \%$ homology to its murine equivalent (Headon and Overbeek 1999; Koppinen et al. 2001; Monreal et al. 1998). Both murine and human receptors comprise regions highly homologous to the TNF receptors, accounting for trimerization and ligand binding, and contain the death domain (Headon et al. 2001; Koppinen et al. 2001; Yan et al. 2000). Within the death domain there is a region interacting with proteins TRAF6 and TRAF3 (Naito et al. 2002), which transfer the signal down the pathway.

The structures of murine Xedar and its human orthologue XEDAR are similar but much smaller (both receptors contain only 297 amino acids each). Like Edar and EDAR, they comprise sequences highly homologous to the TNF receptors, and both contain the death domain. These sequences are responsible for trimerization and ligand binding.

Eda-A1 binding to Edar leads to the recruitment of a protein named Edaradd (Edar associated death domain), which binds to the C-terminal region of Edar (Chen et al. 2001; Elomaa et al. 2001).

Murine Edaradd, encoded by the $\mathrm{cr}$ (crinkled) gene and its human orthologue EDARADD, encoded by EDARADD, show $80 \%$ homology. Both proteins contain 198 amino acids and comprise a structural motif, similar to that present in Myd88, which participates in signal transduction involving interleukin 1 and Toll receptors (Yan et al. 2002). This motif is responsible for binding to the death domain of Edar or EDAR (Headon et al. 2001; Yan et al. 2002).

Edaradd is co-expressed with Edar in epithelial cells during the formation of skin appendages. It acts as an Edar adaptor molecule linking this receptor to a RING-domain of Traf6 protein (Megas et al. 2011), which strongly activates the NFkB (nuclear factor $\mathrm{kB}$ ) pathway (Headon et al. 2001; Yan et al. 2002), and weakly activates the JNK pathway as well as the caspase-independent cell death pathway (Kumar et al. 2001; Mikkola and Thesleff 2003).

In contrast, the binding of Eda-A2 to Xedar leads to an interaction of its intracellular domain with Traf3 and/or Traf6, and in the consequence activation of both JNK (c-Jun N-terminal kinase) and NFKB pathways (Sinha et al. 2002). This interaction, however, does not require Edaradd. In humans, these relations seems identical.

\section{Activation of the NFKB pathway}

The NFKB pathway is activated by TRAF proteins TRAF6 being the principal one (Naito et al. 2002). TRAF6, is an E2 ubiquitin (E2) ligase and acts as a homodimer, which interacts with the heterodimer E2/E13 (Yin et al. 2009). The N-terminal domain, responsible for dimerization, contains four zinc finger motifs required for activation of the NFKB and JNK pathways
(Chung et al. 2007). The C-terminal region of TRAF6 is responsible for interaction with the TNF $\alpha$-like receptors including EDAR (Chung et al. 2007; Yin et al. 2009), and does not contribute to the activation of the NFKB pathway (Megas et al. 2011).

The interaction of EDARADD with TRAF6 recruits TAK1-binding proteins, TAB1 and TAB2 (Morlon et al. 2005). TAB1 and TAB2 activate the TAK1 (TGF $\beta$-activated kinase 1) multisubunit complex composed of two kinases, IKK $1 / \alpha$ and IKK $2 / \beta$, which phosphorylate $\mathrm{kB}$ inhibitors $\alpha$ and $\beta$ respectively, (DiDonato et al. 1997) as well as a structural component IKK $\gamma$ (NEMO) (Deng et al. 2000). TAK1 probably contains other subunits such as Cdc37 and hsp90 (Chen 2005; Israel 2010). NEMO, which is composed of two coiled coil (CC) domains, interacts with the IKK $1 / \alpha$, IKK $2 / \beta$ through the $\mathrm{N}$-terminal end of the $\mathrm{CC} 1$ domain, comprising a zinc finger motif (Chung et al. 2007), whereas the $\mathrm{CC} 2$ domain containing a leucine zipper is required for oligomerization of the complex (Agou et al. 2004). NEMO itself exhibits no catalytic properties and does not activate $N F \kappa B$ in response to $\mathrm{TNF} \alpha$, interleukin-1b, or lipopolysaccharide (Yamaoka et al. 1998).

Polyubiquitination of TRAF6 promotes activation of the TAB1/TAK1/TAB2 complex through several phosphorylation events involving various kinases, including a serinethreonine kinase IRAK (IL-1 receptor-associated kinase), an accessory protein recruited by interleukin-1 receptor and interacting with TRAF6 (Cao et al. 1996). It has been postulated that IRAK might play a role of an activator of EDAR signaling (Liu et al. 2008).

Another protein, CYLD which deubiqitinates TRAF6 (Jono et al. 2004; Kovalenko et al. 2003; Yoshida et al. 2005), and is negatively regulated by specific TNF receptors (Trompouki et al. 2003), might play a role of a silencer of EDAR signaling, since mutations in CYLD predispose not only to skin tumors (cylidromatosis) (Saggar et al. 2008), but also to the development of tumors of eccrine sweat glands and hair follicles (Brummelkamp et al. 2003; Trompouki et al. 2003).

Activation of the TAK1 complex leads to phosphorylation of $\operatorname{I\kappa } B \alpha$, and $\operatorname{I\kappa } B \beta$ triggering their polyubiquitination and subsequent degradation in proteasomes, which determines the translocation of NFKB to the nucleus (Doffinger et al. 2001).

Depending on the activating signal and the cell type, two NFKB pathways, the canonical (depending on IKK $\beta$ and NEMO) and the non-canonical one (depending exclusively on IKK $\alpha$ ) have been distinguished (Israel 2010).

$\mathrm{NF} K \mathrm{~B}$ is a dimer composed of two out of five Relhomology proteins (Perkins 2007). It remains bound to IKB and sequestered in the cytoplasm. After translocation to the nucleus, NF KB stimulates transcription of target genes (Smahi et al. 2002). The activation of NFKB is shown in Fig. 1. 


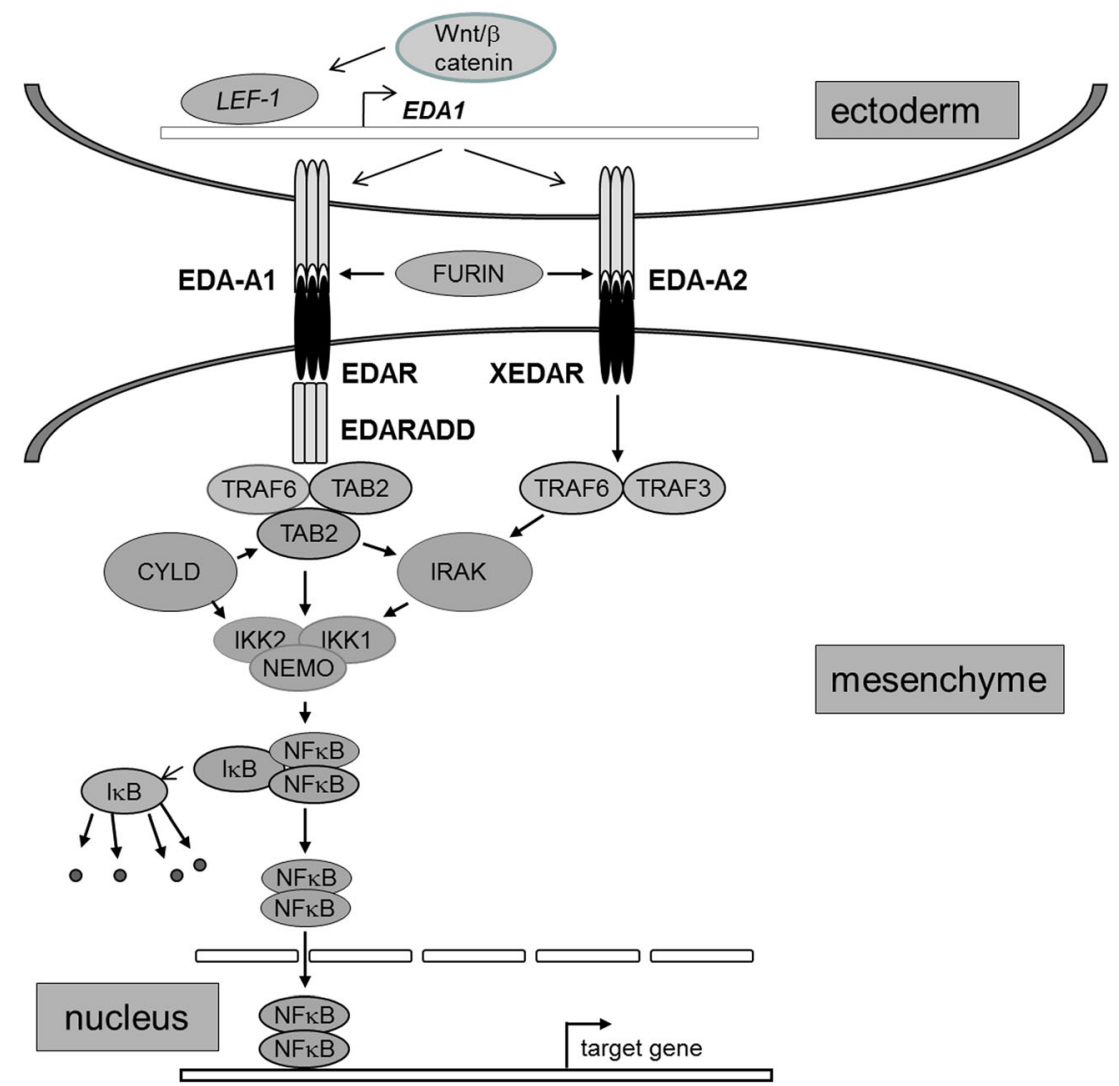

Fig. $1 \mathrm{TNF} \alpha$-related signal transduction pathway participating in the differentiation of skin appendages. Only EDA-A1, EDA1R and EDARADD are specific for the pathway. EDI is expressed in interfollicular cells. Its transcription is controlled by the $\mathrm{Wnt} / \beta$-catenin pathway and requires LEF-1. The membrane-bound protein product of $E D 1$ is cleaved by furin-like proteases to obtain soluble ligands. EDA-A1 binds to EDAR which recruits EDARADD. Both are expressed in follicular cells. EDA-A2 binds to XEDAR, which does not require a

Although in mice, deficient in a NFkB gene, no symptoms similar to the deficiency of Eda-A1 have been observed (Gugasyan et al. 2004), the phenotype of transgenic mice expressing a degradation-resistant I $k \mathrm{~B}$ is very similar to that of Tabby mice suggesting that NFKB is essential for differentiation of skin appendages ( Schmidt-Ullrich et al. 2001). Moreover, it has been demonstrated that in the developing skin appendages, the Eda-A1-dependent expression of transgenic reporter constructs is required for the action of $\mathrm{NFKB}$ (Pispa et al. 2008; Schmidt-Ullrich et al. 2001), confirming earlier reports on NFKB involvement in the differentiation of skin appendages.

Thus EDA-A1, through EDAR and a number of signal transducing proteins, ultimately activates NFKB to stimulate transcription of the genes whose protein products are involved in the initiation, formation, and differentiation of skin appendages.

The complexity of the interactions between the constituents of signal transduction pathways initiated by EDA-1 and EDA2 is illustrated by Fig. 2. Although the role of EDAR signaling protein adaptor to react with TRAF proteins. The remaining components are used by other signaling pathways that converge on NFKB. NFKB stimulates transcription of target genes, and their protein product interacts with several signaling pathways including Shh and BMP. Mutations of EDI cause X-linked HED, mutations of EDA1R or of $E D A R A D D$ cause autosomal (either dominant or recessive) forms of HED. Mutations in NEMO cause X-linked HED associated with immunodeficiency, osteopetrosis, and lymphedema. For details see text

in the processes of differentiation of skin appendages has been relatively well defined, the role of XEDAR signaling in these processes is not fully understood.

\section{Consequences of mutations of the genes encoding components of the TNF $\alpha$-related signaling pathway}

The vast majority of HED cases harbor mutations in EDA. Hemizygous males present the "classical" HED phenotype, but in the heterozygous female, expression of the symptoms varies considerably due to different levels of inactivation of the X-chromosome (Bartstra et al. 1994; Cambiaghi et al. 2000).

To date, more than 200 mutations of EDA1 have been described. Most are point mutations and about $30 \%$ constitute insertions or deletions, some leading to a frame shift and as a consequence, truncation of the protein product of the gene. About $20 \%$ are mutations resulting from aberrant splicing (Table 1). 


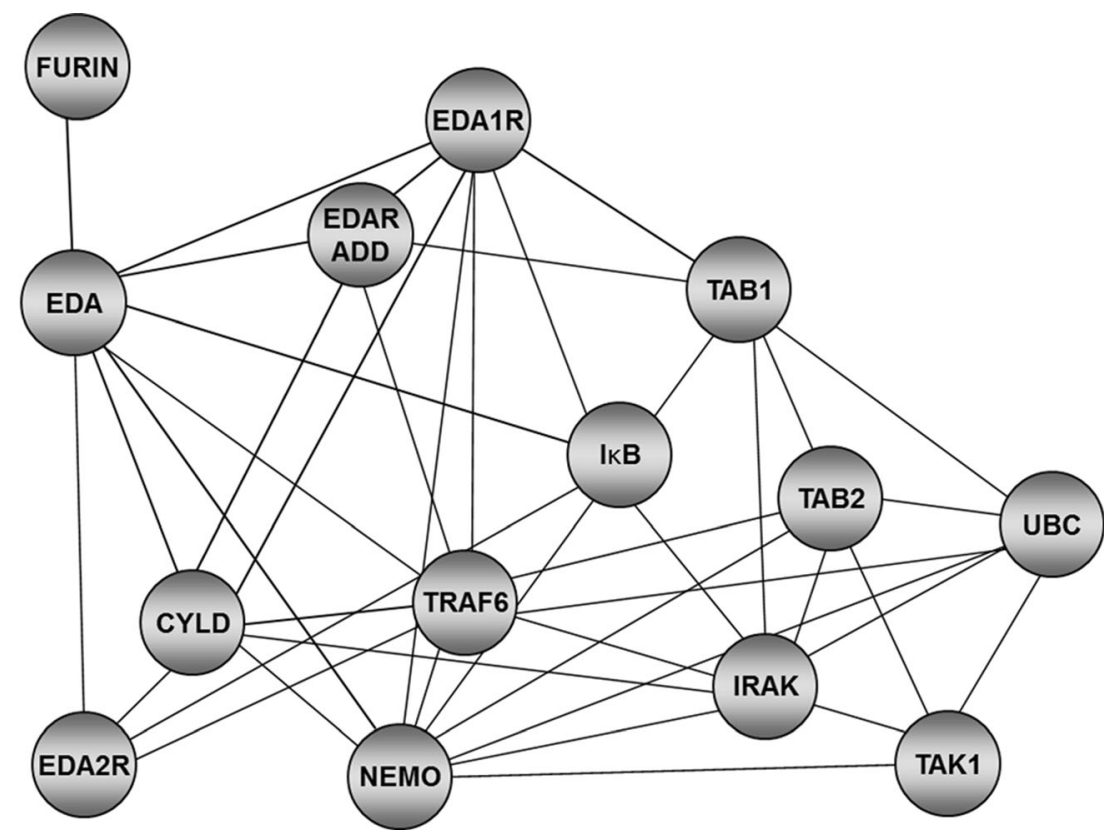

Fig. 2 Interaction of proteins involved in signal transduction via the $\mathrm{TNF} \alpha$-related signal transduction pathway (based on http://string-db. org, simplified). EDA, two isoforms of ectodysplasin A; EDA-A1 isoform, binds to EDA-A1 receptor (EDAR); EDA-A2 isoform, binds to EDA-A2 receptor (XEDAR); EDARADD adapter protein, interacts with EDAR; CYLD, deubiqitinates TRAF6; FURIN, endopeptidase recognizing the $\mathrm{RX}(\mathrm{K} / \mathrm{R}) \mathrm{R}$ sequence in EDA precursor; IKB, inhibitor NFKB; IRAK, indirect NFKB activator; NEMO, regulatory subunit of the IKK complex; TAK1, TGF-beta activated kinase 1; TAB1, activated kinase 1 binding protein; TAB2, activated kinase 2 binding protein; TRAF6, ubiquitin ligase; CYLD, deubiqitinates TRAF6; UBC, ubiquitin $\mathrm{C}$

We reported the first mutation of TRAF6 in a female patient displaying mild symptoms typical of HED (Wisniewski and Trzeciak 2012a). Sequencing analysis of one DNA strand in this patient revealed a deletion of eight nucleotides (c.10741081delCAACTTTG) in the 5' fragment of the last exon of TRAF6, while no deletion was detected in the other DNA strand, indicating a heterozygous mutation. This deletion causes a shift of the reading frame and as a consequence, premature termination of translation 15 amino acids downstream of the mutation. This results in a truncated TRAF6 devoid of a major part of the $\mathrm{C}$-terminal region that is responsible for interacting with EDAR. Because no mutations were found in $E D A, E D A R$, and $E D A R A D D$, and there were no signs of immunodeficiency and incontinentia pigmenti, which might suggest a mutation in $N E M O$, we postulated that this mutation was causative (Wisniewski and Trzeciak 2012a). Functional assays, involving coimmunoprecipitation studies and pull down assay, have clearly shown that the mutant TRAF6 protein is capable of forming a complex with TAK1 and TAB2, but it has completely lost the affinity to EDARADD (Fujikawa et al. 2013). These results confirmed our suggestion (Wisniewski and Trzeciak 2012a) that the novel mutation of TRAF6 can cause symptoms of HED.

Because all genes mentioned above encode proteins of the same signal transduction pathway, it is not surprising that individuals having defects in one or more of these genes 
display a similar phenotype and exhibit similar symptoms, albeit of a different intensity of expression (Kobielak et al. 2001).

Until recently, no mutations were reported in the genes encoding other proteins involved in the interaction with TRAF6 and translocation of NFKB to the cell nucleus, except of the mutation located in the gene encoding $\operatorname{IKB} \alpha$ which caused the autosomal dominant form of ectodermal dysplasia associated with T-cell deficiency (Courtois et al. 2003).

Substantial evidence indicates that XEDAR upon interaction with EDA-A2 induces caspase-dependent apoptosis in osteosarcoma cell lines (Chung et al. 2007; Sinha and Chaudhary 2004), while expression of a dominant negative XEDAR suppresses feather development in chickens (Drew et al. 2007). Moreover, in humans, a single nucleotide polymorphism of XEDAR was associated with male-pattern baldness (Prodi et al. 2008; Redler et al. 2012) and it was demonstrated that XEDAR, like EDAR, interacts with TRAF6 (Naito et al. 2002). Taken together, these findings indicate that XEDAR might participate in signal transduction from ectoderm to mesenchyme, and that mutations in XEDAR might disturb differentiation of skin appendages. However, no symptoms typical of ectodermal dysplasia were reported in Xedar knock-out mice (Newton et al. 2004) and until recently, no mutations in XEDAR were found in patients with symptoms typical of HED, suggesting that XEDAR is not involved in the differentiation of skin appendages.

However, we have reported a new mutation (c.252delG) of $X E D A R$ in a patient with symptoms typical of HED, in whom no mutations in EDA,EDA1R, EDARADD, and TRAF6 have been detected (Wisniewski and Trzeciak 2012b). This novel mutation leads to a frameshift and as a consequence to a deletion of the entire intracellular and transmembrane domains of XEDAR.

Although the Eda-A2/Xedar pathway has not been associated with the mouse variant of HED, it has been demonstrated that Xedar activates the NF- $\mathrm{kB}$ pathway in a ligand-dependent fashion with the mediation of Traf 6 and the kinases of the IKK complex (Naito et al. 2002). Moreover, it has been shown that Traf6 binds strongly to the intracellular domain of Xedar, and that Traf6-deficient mice display symptoms typical of the mouse variant of HED (Naito et al. 2002). These observations suggest that the protein products of both Edar and Xedar can interact with TRAF6 and function in the NF $\kappa B$ signaling.

Based on our results (Wisniewski and Trzeciak 2012b), it could be reasoned that the deletion of an entire TRAF6interacting domain of XEDAR makes activation of the NFkB pathway impossible.

Thus under normal conditions the protein product of $X E D A R$ might participate in the differentiation of skin appendages and this mutation might be responsible for the symptoms typical of HED. This will be the first mutation in $X E D A R$ associated with symptoms of HED. However, to confirm our findings (Wisniewski and Trzeciak 2012b) that the (c.252delG) mutation is causative a functional assay is required.

\section{Chromosomal localization and the mode of inheritance of mutations of genes responsible for HED}

$E D A$ is located on the $\mathrm{X}$ chromosome (Xq12-q13) and mutations of this gene are therefore transmitted by heterozygous mothers to their offspring. This is the reason why the symptoms of HED (ECTD, 300451) are much more pronounced in the hemizygous males than in the heterozygous females who are carriers of these mutations (Table 1).

EDAR is situated on chromosome 2q12.3 (Monreal et al. 1999). Mutations in this gene are therefore inherited in either autosomal dominant (ECTD10A, phenotype MIM 129490) (Fujikawa et al. 2013; Fujimoto et al. 2008; Monreal et al. 1999; van der Hout et al. 2008) or autosomal recessive way (ECTD10B, phenotype MIM 224900) (Chassaing et al. 2006; Lind et al. 2006; Megarbane et al. 2008; Naeem et al. 2005; Shimomura et al. 2004).

EDARADD localization (1q42.3) indicates that mutations of this gene can be inherited in either an autosomal dominant or recessive way (Bal et al. 2007). Similarly, deficiency of EDAR causes either autosomal dominant (ECTD11A, phenotype MIM 614940) or autosomal recessive (ECTD11B, phenotype MIM 614941) forms (Bal et al. 2007; Headon et al. 2001; Munoz et al. 1997).

NEMO like EDA and XEDAR is located on the X chromosome (Xq28) and mutations of this gene are usually transmitted by heterozygous mothers, but "typical" symptoms of HED are seen only in hemizygous males. In heterozygous females the symptoms are mild or negligible. The symptoms of HED due to in frame mutations in NEMO (OMIM 308300) are most often accompanied by immunodeficiency and incontinentia pigmenti (EDA-ID). When mutations lead to truncation of a protein product of the gene, immunodeficiency is accompanied by osteopetrosis and lymphedema (OL-EDA-ID). In most cases a severe genodermatosis is associated with hypodontia, peg-shaped or malformed teeth and in some patients ophtalmological and neurological problems (Chassaing et al. 2010).

TRAF6 is located on chromosome $11 \mathrm{p} 12$. The first mutation reported in TRAF6 (Wisniewski and Trzeciak 2012a) originated de novo. Theoretically, the inheritance pattern of HED due to mutations in TRAF6, should be autosomal dominant, as in our patient, since only mild symptoms of HED were detected in his heterozygous mother.

The novel mutation found in $X E D A R$, which is located on the $\mathrm{X}$ chromosome (20p1), similar to mutations in EDAR and 
$N E M O$, was transmitted by a heterozygous mother to her son (Wisniewski and Trzeciak 2012b).

\section{Clinical symptoms and prosthetic treatment of hypohidrotic ectodermal dysplasia}

The main clinical symptoms characteristic of HED include reduced ability to sweat (hypohidrosis), the lack of several or more teeth (hypodontia), and sparse hair (hypotrichosis).

Reduction in the ability to sweat causes overheating and this in turn results in about $30 \%$ mortality rate in early childhood if the disease is not properly diagnosed and treated (Clarke et al. 1987). Consequently, due to disturbed thermal perception, the patients suffer from overheating (hyperthermia), particularly in the Summer. Dentition abnormalities include incorrect numbers and shape of teeth (Fig. 3) and leads to impaired mastication and speech defects as well as an esthetic discomfort. Defects in the number of teeth are very common. Third molars (wisdom teeth) do not develop in $25 \%$ of the world's population. The number of teeth range from over a dozen (hypodontia) through several (oligodontia) to the lack of all permanent teeth (anodontia) or even the lack of both permanent and decidual teeth (aplasia) (De Coster et al. 2009; Nieminen 2009).

The teeth are frequently conical, bulbous or taurodontic and widely spaced, without any points of contact. The compromised enamel is prone to caries and mechanical damage. Tooth eruption can be obstructed and the number of teeth can be significantly reduced. Some teeth fail to emerge in the oral cavity.

Atrophic inflammation of the mucosa of the oral cavity and the throat, a hoarse voice, and swallowing difficulties are also signs of HED.

The patients' hair is thin, sparse, fragile and light-colored. The skin is thin, pale, very delicate and is dry and exfoliating with insufficient pigmentation, except for the region around the eyes and mouth where it is wrinkled and hyperpigmented, giving a prematurely aged appearance (Mikkola 2009; Wisniewski et al. 2002). The skin is vulnerable to infection, irritation, and mechanical trauma and this can be attributed to the dysfunction of the dermal glands and the presence of a thin
Fig. 3 Phenotype of patients with HED caused by mutations of TNF-related signaling pathway. (Reproduced with permission of the editor from: Wiśniewski S.A., Trzeciak W.H., Homines hominibus 6: 21-28, 2010 (a) Side view of the patient; (b) dentition; (c) mutated gene

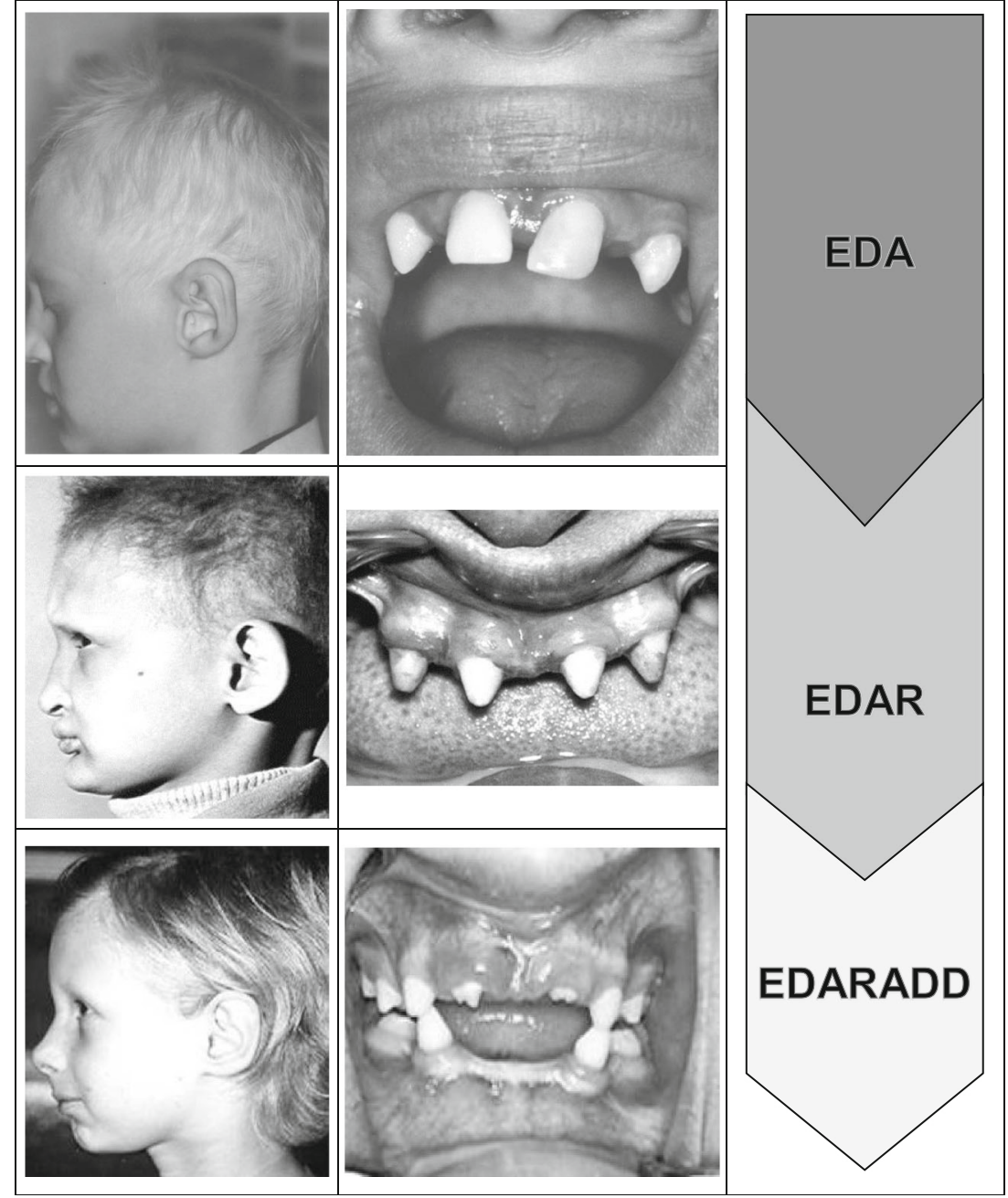


fatty layer. The skin on the palms and soles exhibits characteristic dermatogliphic patterns. The nails can be poorly or abnormally formed and discolored. The ocular surface abnormalities (corneal lesions and inflammation), caused by a lack of Meibomian's glands, have also been reported (Cui et al. 2005; Kaercher 2004).

All of these manifestations are often accompanied by impaired vision and hearing as well as frequent infections of the respiratory tract (Dietz et al. 2013) that can be attributed to dry airways and mucous membranes.

Some patients display facial dysmorphism and other abnormalities including a prominent forehead, depressed nasal bridge, thick lips, and/or a pointed chin.

\section{Treatment of patients with hypohidrotic ectodermal dysplasia}

Although HED gene therapy has been attempted in mice (Gaide and Schneider 2003) and dogs (Casal et al. 1997, 2007) to date no appropriate protocol for gene therapy in humans has been reported.

There is not much we can do for the patient in terms of treatment. Treatment involves avoidance of overheating and application of creams that protect the dry and delicate skin from possible damage. Tooth abnormalities can be corrected by prosthetic treatment which needs to be highly individualized due to variation in the degree of hypo- or oligodontia.

Removable dentures of a varying plate size can be used in the case of persons aged up to 18 years. Generally, partially removable prostheses with a small number of retention clasps are applied in order to ensure the proper development of the prosthetic base bone structure. Effective anchoring of such dentures requires preparing retention sites with the use of composite materials on existing, abnormally formed teeth, which are often icicle-shaped. Adaptation of the removable prosthesis is necessitated by structural bone changes in the base, coupled with the shape of the few remaining teeth in the dental arch, and involves relining or replacement of the restoration (Fig. 4). It is very important to prepare the acrylic mucosal part of the complete or partial denture in the proper way. The use of thin tin foil in the dental laboratory protects the dry and delicate oral mucosa from the traumatic impact of the plate. Emphasis should also be placed on systematic check-ups of the prosthetic base, denture corrections, and instructing the patient to apply specific hygienic procedures.

In the case of anodontia, removable prostheses should be applied. If the patient is under 18 years of age, the prostheses should be periodically replaced by new, larger ones, to ensure the proper development of the bone structure of the prosthetic base.

\section{Concluding remarks}

Within the last years, considerable progress has been made in better understanding the process of signal transduction from ectoderm to mesenchyme. This signal is responsible for the initiation, formation, and differentiation of skin appendages. The structure of the genes encoding the components of the $\mathrm{TNF} \alpha$-related signaling pathway has been resolved and the functions of the protein products of these genes precisely characterized. Functional assays have been developed for nearly all of these proteins. A number of new mutations of the genes encoding components of the TNF $\alpha$-related signaling pathway have been reported. However, these new discoveries have rarely been supported by functional assays and this has cast doubt whether all of the reported mutations are causative. This applies mainly to the missense mutations which usually do not change the structure of a protein product of the gene to a large extent. Nucleotide insertion or deletion within the sequence of a gene does not necessarily require a functional assay because such mutations usually cause a shift in the reading frame and as a result, truncation of the protein, which may lack some functionally important domain(s) which interact with other proteins of the TNF $\alpha$-related signaling pathway.

Moreover, the normal structure of the gene is not sufficient to guarantee that the protein product of this gene is synthesized, because the gene might not be expressed. In the case where mutations in the genes encoding proteins involved in
Fig. 4 The effects of prosthetic treatment of one of our patients with HED caused by mutation of $E D A R$ (a) before the treatment. Note four teeth of conical shape in mandible and none in maxilla. (b) after the prosthetic treatment

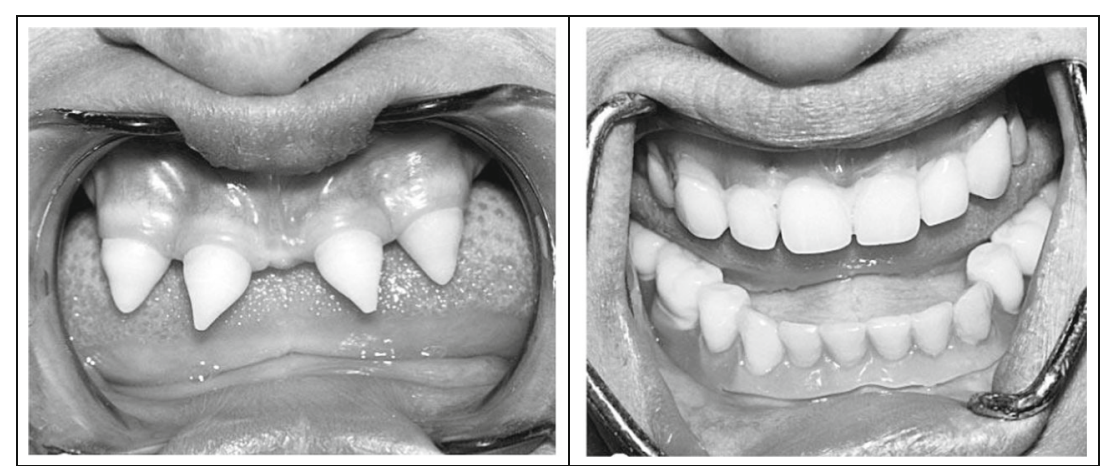


the TNF $\alpha$-related signaling pathway were not detected, it should therefore be proved that the genes were expressed. Therefore, further investigations on the mode of transcriptional regulation of the genes encoding components of the TNF $\alpha$ related signaling pathway are still required.

Acknowledgments The authors are grateful to Dr. Marcin Hołysz for editorial assistance and to Dr. Tomasz Lehmann for designing and preparation of figures.

Critical reading and editorial correction of the manuscript by Dr. Gary Schoenhals is gratefully acknowledged.

Open Access This article is distributed under the terms of the Creative Commons Attribution 4.0 International License (http:// creativecommons.org/licenses/by/4.0/), which permits unrestricted use, distribution, and reproduction in any medium, provided you give appropriate credit to the original author(s) and the source, provide a link to the Creative Commons license, and indicate if changes were made.

\section{References}

Adaimy L, Chouery E, Megarbane H, Mroueh S, Delague V, Nicolas E, Belguith H, de Mazancourt P, Megarbane A (2007) Mutation in WNT10A is associated with an autosomal recessive ectodermal dysplasia: the odonto-onycho-dermal dysplasia. Am J Hum Genet $81: 821-828$

Agou F, Traincard F, Vinolo E, Courtois G, Yamaoka S, Israel A, Veron $\mathrm{M}$ (2004) The trimerization domain of NEMO is composed of the interacting C-terminal CC2 and LZ coiled-coil subdomains. J Biol Chem 279:27861-27869

Arte S, Parmanen S, Pirinen S, Alaluusua S, Nieminen P (2013) Candidate gene analysis of tooth agenesis identifies novel mutations in six genes and suggests significant role for WNT and EDA signaling and allele combinations. PLoS One 8:e73705

Bal E, Baala L, Cluzeau C, El Kerch F, Ouldim K, Hadj-Rabia S, Bodemer C, Munnich A, Courtois G, Sefiani A, Smahi A (2007) Autosomal dominant anhidrotic ectodermal dysplasias at the EDARADD locus. Hum Mutat 28:703-709

Bartstra HL, Hulsmans RF, Steijlen PM, Ruige M, de Die-Smulders CE, Cassiman JJ (1994) Mosaic expression of hypohidrotic ectodermal dysplasia in an isolated affected female child. Arch Dermatol 130: $1421-1424$

Bayes M, Hartung AJ, Ezer S, Pispa J, Thesleff I, Srivastava AK, Kere J (1998) The anhidrotic ectodermal dysplasia gene (EDA) undergoes alternative splicing and encodes ectodysplasin-A with deletion mutations in collagenous repeats. Hum Mol Genet 7:1661-1669

Brummelkamp TR, Nijman SM, Dirac AM, Bernards R (2003) Loss of the cylindromatosis tumour suppressor inhibits apoptosis by activating NF-kappaB. Nature 424:797-801

Cambiaghi S, Restano L, Paakkonen K, Caputo R, Kere J (2000) Clinical findings in mosaic carriers of hypohidrotic ectodermal dysplasia. Arch Dermatol 136:217-224

Cao Z, Xiong J, Takeuchi M, Kurama T, Goeddel DV (1996) TRAF6 is a signal transducer for interleukin-1. Nature 383:443-446

Casal ML, Jezyk PF, Greek JM, Goldschmidt MH, Patterson DF (1997) X-linked ectodermal dysplasia in the dog. J Hered 88:513-517

Casal ML, Lewis JR, Mauldin EA, Tardivel A, Ingold K, Favre M, Paradies F, Demotz S, Gaide O, Schneider P (2007) Significant correction of disease after postnatal administration of recombinant ectodysplasin A in canine X-linked ectodermal dysplasia. Am J Hum Genet 81:1050-1056
Chassaing N, Bourthoumieu S, Cossee M, Calvas P, Vincent MC (2006) Mutations in EDAR account for one-quarter of non-ED1-related hypohidrotic ectodermal dysplasia. Hum Mutat 27:255-259

Chassaing N, Cluzeau C, Bal E, Guigue P, Vincent MC, Viot G, Ginisty D, Munnich A, Smahi A, Calvas P (2010) Mutations in EDARADD account for a small proportion of hypohidrotic ectodermal dysplasia cases. Br J Dermatol 162:1044-1048

Chen ZJ (2005) Ubiquitin signalling in the NF-kappaB pathway. Nat Cell Biol 7:758-765

Chen Y, Molloy SS, Thomas L, Gambee J, Bachinger HP, Ferguson B, Zonana J, Thomas G, Morris NP (2001) Mutations within a furin consensus sequence block proteolytic release of ectodysplasin-A and cause X-linked hypohidrotic ectodermal dysplasia. Proc Natl Acad Sci U S A 98:7218-7223

Chung JY, Lu M, Yin Q, Lin SC, Wu H (2007) Molecular basis for the unique specificity of TRAF6. Adv Exp Med Biol 597:122-130

Clarke A, Phillips DI, Brown R, Harper PS (1987) Clinical aspects of Xlinked hypohidrotic ectodermal dysplasia. Arch Dis Child 62:989996

Clevers H (2006) Wnt/beta-catenin signaling in development and disease. Cell 127:469-480

Cluzeau C, Hadj-Rabia S, Jambou M, Mansour S, Guigue P, Masmoudi S, Bal E, Chassaing N, Vincent MC, Viot G, Clauss F, Maniere MC, Toupenay S, Le Merrer M, Lyonnet S, Cormier-Daire V, Amiel J, Faivre L, de Prost Y, Munnich A, Bonnefont JP, Bodemer C, Smahi A (2011) Only four genes (EDA1, EDAR, EDARADD, and WNT10A) account for $90 \%$ of hypohidrotic/anhidrotic ectodermal dysplasia cases. Hum Mutat 32:70-72

Courtois G, Smahi A, Reichenbach J, Doffinger R, Cancrini C, Bonnet M, Puel A, Chable-Bessia C, Yamaoka S, Feinberg J, Dupuis-Girod S, Bodemer C, Livadiotti S, Novelli F, Rossi P, Fischer A, Israel A, Munnich A, Le Deist F, Casanova JL (2003) A hypermorphic IkappaBalpha mutation is associated with autosomal dominant anhidrotic ectodermal dysplasia and T cell immunodeficiency. J Clin Invest 112:1108-1115

Cui CY, Smith JA, Schlessinger D, Chan CC (2005) X-linked anhidrotic ectodermal dysplasia disruption yields a mouse model for ocular surface disease and resultant blindness. Am J Pathol 167:89-95

Dann CE, Hsieh JC, Rattner A, Sharma D, Nathans J, Leahy DJ (2001) Insights into Wnt binding and signalling from the structures of two Frizzled cysteine-rich domains. Nature 412:86-90

De Coster PJ, Marks LA, Martens LC, Huysseune A (2009) Dental agenesis: genetic and clinical perspectives. J Oral Pathol Med 38:1-17

Deng L, Wang C, Spencer E, Yang L, Braun A, You J, Slaughter C, Pickart C, Chen ZJ (2000) Activation of the IkappaB kinase complex by TRAF6 requires a dimeric ubiquitin-conjugating enzyme complex and a unique polyubiquitin chain. Cell 103:351-361

DiDonato JA, Hayakawa M, Rothwarf DM, Zandi E, Karin M (1997) A cytokine-responsive IkappaB kinase that activates the transcription factor NF-kappaB. Nature 388:548-554

Dietz J, Kaercher T, Schneider AT, Zimmermann T, Huttner K, Johnson R, Schneider H (2013) Early respiratory and ocular involvement in X-linked hypohidrotic ectodermal dysplasia. Eur J Pediatr 172: 1023-1031

Doffinger R, Smahi A, Bessia C, Geissmann F, Feinberg J, Durandy A, Bodemer C, Kenwrick S, Dupuis-Girod S, Blanche S, Wood P, Rabia SH, Headon DJ, Overbeek PA, Le Deist F, Holland SM, Belani K, Kumararatne DS, Fischer A, Shapiro R, Conley ME, Reimund E, Kalhoff H, Abinun M, Munnich A, Israel A, Courtois G, Casanova JL (2001) X-linked anhidrotic ectodermal dysplasia with immunodeficiency is caused by impaired NF-kappaB signaling. Nat Genet 27:277-285

Drew CF, Lin CM, Jiang TX, Blunt G, Mou C, Chuong CM, Headon DJ (2007) The Edar subfamily in feather placode formation. Dev Biol 305:232-245 
Durmowicz MC, Cui CY, Schlessinger D (2002) The EDA gene is a target of, but does not regulate Wnt signaling. Gene 285:203-211

Elomaa O, Pulkkinen K, Hannelius U, Mikkola M, Saarialho-Kere U, Kere J (2001) Ectodysplasin is released by proteolytic shedding and binds to the EDAR protein. Hum Mol Genet 10:953-962

Ezer S, Bayes M, Elomaa O, Schlessinger D, Kere J (1999) Ectodysplasin is a collagenous trimeric type II membrane protein with a tumor necrosis factor-like domain and co-localizes with cytoskeletal structures at lateral and apical surfaces of cells. Hum Mol Genet 8:20792086

Ferguson BM, Brockdorff N, Formstone E, Ngyuen T, Kronmiller JE, Zonana J (1997) Cloning of Tabby, the murine homolog of the human EDA gene: evidence for a membrane-associated protein with a short collagenous domain. Hum Mol Genet 6:1589-1594

Fujikawa H, Farooq M, Fujimoto A, Ito M, Shimomura Y (2013) Functional studies for the TRAF6 mutation associated with hypohidrotic ectodermal dysplasia. Br J Dermatol 168:629-633

Fujimoto A, Ohashi J, Nishida N, Miyagawa T, Morishita Y, Tsunoda T, Kimura R, Tokunaga K (2008) A replication study confirmed the EDAR gene to be a major contributor to population differentiation regarding head hair thickness in Asia. Hum Genet 124:179-185

Gaide O, Schneider P (2003) Permanent correction of an inherited ectodermal dysplasia with recombinant EDA. Nat Med 9:614-618

Gugasyan R, Voss A, Varigos G, Thomas T, Grumont RJ, Kaur P, Grigoriadis G, Gerondakis S (2004) The transcription factors c-rel and RelA control epidermal development and homeostasis in embryonic and adult skin via distinct mechanisms. Mol Cell Biol 24: $5733-5745$

He H, Han D, Feng H, Qu H, Song S, Bai B, Zhang Z (2013) Involvement of and interaction between WNT10A and EDA mutations in tooth agenesis cases in the Chinese population. PLoS One 8:e80393

Headon DJ, Overbeek PA (1999) Involvement of a novel Tnf receptor homologue in hair follicle induction. Nat Genet 22:370-374

Headon DJ, Emmal SA, Ferguson BM, Tucker AS, Justice MJ, Sharpe PT, Zonana J, Overbeek PA (2001) Gene defect in ectodermal dysplasia implicates a death domain adapter in development. Nature 414:913-916

Israel A (2010) The IKK complex, a central regulator of NF-kappaB activation. Cold Spring Harb Perspect Biol 2:a000158

Jono H, Lim JH, Chen LF, Xu H, Trompouki E, Pan ZK, Mosialos G, Li JD (2004) NF-kappaB is essential for induction of CYLD, the negative regulator of NF-kappaB: evidence for a novel inducible autoregulatory feedback pathway. J Biol Chem 279:36171-36174

Kaercher T (2004) Ocular symptoms and signs in patients with ectodermal dysplasia syndromes. Graefes Arch Clin Exp Ophthalmol 242: 495-500

Kapadia H, Mues G, D'Souza R (2007) Genes affecting tooth morphogenesis. Orthod Craniofac Res 10:237-244

Kere J, Srivastava AK, Montonen O, Zonana J, Thomas N, Ferguson B, Munoz F, Morgan D, Clarke A, Baybayan P, Chen EY, Ezer S, Saarialho-Kere U, de la Chapelle A, Schlessinger D (1996) Xlinked anhidrotic (hypohidrotic) ectodermal dysplasia is caused by mutation in a novel transmembrane protein. Nat Genet 13:409-416

Kobielak K, Kobielak A, Roszkiewicz J, Wierzba J, Limon J, Trzeciak WH (2001) Mutations in the EDA gene in three unrelated families reveal no apparent correlation between phenotype and genotype in the patients with an X-linked anhidrotic ectodermal dysplasia. Am J Med Genet 100:191-197

Koppinen P, Pispa J, Laurikkala J, Thesleff I, Mikkola ML (2001) Signaling and subcellular localization of the TNF receptor Edar. Exp Cell Res 269:180-192

Kovalenko A, Chable-Bessia C, Cantarella G, Israel A, Wallach D, Courtois G (2003) The tumour suppressor CYLD negatively regulates NF-kappaB signalling by deubiquitination. Nature 424:801805
Kumar A, Eby MT, Sinha S, Jasmin A, Chaudhary PM (2001) The ectodermal dysplasia receptor activates the nuclear factor-kappaB, JNK, and cell death pathways and binds to ectodysplasin A. J Biol Chem 276:2668-2677

Laurikkala J, Pispa J, Jung HS, Nieminen P, Mikkola M, Wang X, Saarialho-Kere U, Galceran J, Grosschedl R, Thesleff I (2002) Regulation of hair follicle development by the TNF signal ectodysplasin and its receptor Edar. Development 129:2541-2553

Lind LK, Stecksen-Blicks C, Lejon K, Schmitt-Egenolf M (2006) EDAR mutation in autosomal dominant hypohidrotic ectodermal dysplasia in two Swedish families. BMC Med Genet 7:80

Liu G, Park YJ, Abraham E (2008) Interleukin-1 receptor-associated kinase (IRAK) -1-mediated NF-kappaB activation requires cytosolic and nuclear activity. Faseb J 22:2285-2296

May P, Woldt E, Matz RL, Boucher P (2007) The LDL receptor-related protein (LRP) family: an old family of proteins with new physiological functions. Ann Med 39:219-228

Megarbane H, Cluzeau C, Bodemer C, Fraitag S, Chababi-Atallah M, Megarbane A, Smahi A (2008) Unusual presentation of a severe autosomal recessive anhydrotic ectodermal dysplasia with a novel mutation in the EDAR gene. Am J Med Genet A 146A:2657-2662

Megas C, Hatzivassiliou EG, Yin Q, Marinopoulou E, Hadweh P, Vignali DA, Mosialos G (2011) Mutational analysis of TRAF6 reveals a conserved functional role of the RING dimerization interface and a potentially necessary but insufficient role of RING-dependent TRAF6 polyubiquitination towards NF-kappaB activation. Cell Signal 23:772-777

Mikkola ML (2009) Molecular aspects of hypohidrotic ectodermal dysplasia. Am J Med Genet A 149A:2031-2036

Mikkola ML, Thesleff I (2003) Ectodysplasin signaling in development. Cytokine Growth Factor Rev 14:211-224

Monreal AW, Zonana J, Ferguson B (1998) Identification of a new splice form of the EDA1 gene permits detection of nearly all X-linked hypohidrotic ectodermal dysplasia mutations. Am J Hum Genet 63:380-389

Monreal AW, Ferguson BM, Headon DJ, Street SL, Overbeek PA, Zonana J (1999) Mutations in the human homologue of mouse dl cause autosomal recessive and dominant hypohidrotic ectodermal dysplasia. Nat Genet 22:366-369

Morlon A, Munnich A, Smahi A (2005) TAB2, TRAF6 and TAK1 are involved in NF-kappaB activation induced by the TNF-receptor, Edar and its adaptator Edaradd. Hum Mol Genet 14:3751-3757

Mostowska A, Kobielak A, Trzeciak WH (2003) Molecular basis of nonsyndromic tooth agenesis: mutations of MSX1 and PAX9 reflect their role in patterning human dentition. Eur J Oral Sci 111:365-370

Munoz F, Lestringant G, Sybert V, Frydman M, Alswaini A, Frossard PM, Jorgenson R, Zonana J (1997) Definitive evidence for an autosomal recessive form of hypohidrotic ectodermal dysplasia clinically indistinguishable from the more common X-linked disorder. Am J Hum Genet 61:94-100

Naeem M, Muhammad D, Ahmad W (2005) Novel mutations in the EDAR gene in two Pakistani consanguineous families with autosomal recessive hypohidrotic ectodermal dysplasia. Br J Dermatol $153: 46-50$

Naito A, Yoshida H, Nishioka E, Satoh M, Azuma S, Yamamoto T, Nishikawa S, Inoue J (2002) TRAF6-deficient mice display hypohidrotic ectodermal dysplasia. Proc Natl Acad Sci U S A 99: 8766-8771

Nawaz S, Klar J, Wajid M, Aslam M, Tariq M, Schuster J, Baig SM, Dahl N (2009) WNT10A missense mutation associated with a complete odonto-onycho-dermal dysplasia syndrome. Eur J Hum Genet 17: $1600-1605$

Newton K, French DM, Yan M, Frantz GD, Dixit VM (2004) Myodegeneration in EDA-A2 transgenic mice is prevented by XEDAR deficiency. Mol Cell Biol 24:1608-1613 
Nieminen P (2009) Genetic basis of tooth agenesis. J Exp Zool B Mol Dev Evol 312B:320-342

Paixao-Cortes VR, Braga T, Salzano FM, Mundstock K, Mundstock CA, Bortolini MC (2011) PAX9 and MSX1 transcription factor genes in non-syndromic dental agenesis. Arch Oral Biol 56:337-344

Perkins ND (2007) Integrating cell-signalling pathways with NF-kappaB and IKK function. Nat Rev Mol Cell Biol 8:49-62

Pinheiro M, Freire-Maia N (1994) Ectodermal dysplasias: a clinical classification and a causal review. Am J Med Genet 53:153-162

Pispa J, Pummila M, Barker PA, Thesleff I, Mikkola ML (2008) Edar and Troy signalling pathways act redundantly to regulate initiation of hair follicle development. Hum Mol Genet 17:3380-3391

Priolo M, Lagana C (2001) Ectodermal dysplasias: a new clinical-genetic classification. J Med Genet 38:579-585

Prodi DA, Pirastu N, Maninchedda G, Sassu A, Picciau A, Palmas MA, Mossa A, Persico I, Adamo M, Angius A, Pirastu M (2008) EDA2R is associated with androgenetic alopecia. J Invest Dermatol 128: 2268-2270

Rao TP, Kuhl M (2010) An updated overview on Wnt signaling pathways: a prelude for more. Circ Res 106:1798-1806

Redler S, Brockschmidt FF, Tazi-Ahnini R, Drichel D, Birch MP, Dobson K, Giehl KA, Herms S, Refke M, Kluck N, Kruse R, Lutz G, Wolff H, Bohm M, Becker T, Nothen MM, Messenger AG, Betz RC (2012) Investigation of the male pattern baldness major genetic susceptibility loci AR/EDA2R and 20p11 in female pattern hair loss. $\mathrm{Br}$ J Dermatol 166:1314-1318

Saggar S, Chernoff KA, Lodha S, Horev L, Kohl S, Honjo RS, Brandt HR, Hartmann K, Celebi JT (2008) CYLD mutations in familial skin appendage tumours. J Med Genet 45:298-302

Schmidt-Ullrich R, Paus R (2005) Molecular principles of hair follicle induction and morphogenesis. Bioessays 27:247-261

Schmidt-Ullrich R, Aebischer T, Hulsken J, Birchmeier W, Klemm U, Scheidereit C (2001) Requirement of NF-kappaB/Rel for the development of hair follicles and other epidermal appendices. Development 128:3843-3853

Shimomura Y, Sato N, Miyashita A, Hashimoto T, Ito M, Kuwano R (2004) A rare case of hypohidrotic ectodermal dysplasia caused by compound heterozygous mutations in the EDAR gene. J Invest Dermatol 123:649-655

Sinha SK, Chaudhary PM (2004) Induction of apoptosis by X-linked ectodermal dysplasia receptor via a caspase 8-dependent mechanism. J Biol Chem 279:41873-41881

Sinha SK, Zachariah S, Quinones HI, Shindo M, Chaudhary PM (2002) Role of TRAF3 and -6 in the activation of the NF-kappa B and JNK pathways by X-linked ectodermal dysplasia receptor. J Biol Chem 277:44953-44961

Smahi A, Courtois G, Rabia SH, Doffinger R, Bodemer C, Munnich A, Casanova JL, Israel A (2002) The NF-kappaB signalling pathway in human diseases: from incontinentia pigmenti to ectodermal dysplasias and immune-deficiency syndromes. Hum Mol Genet 11:23712375

Srivastava AK, Pispa J, Hartung AJ, Du Y, Ezer S, Jenks T, Shimada T, Pekkanen M, Mikkola ML, Ko MS, Thesleff I, Kere J, Schlessinger
D (1997) The Tabby phenotype is caused by mutation in a mouse homologue of the EDA gene that reveals novel mouse and human exons and encodes a protein (ectodysplasin-A) with collagenous domains. Proc Natl Acad Sci U S A 94:13069-13074

Trompouki E, Hatzivassiliou E, Tsichritzis T, Farmer H, Ashworth A, Mosialos G (2003) CYLD is a deubiquitinating enzyme that negatively regulates NF-kappaB activation by TNFR family members. Nature 424:793-796

van den Boogaard MJ, Creton M, Bronkhorst Y, van der Hout A, Hennekam E, Lindhout D, Cune M, Ploos van Amstel HK (2012) Mutations in WNT10A are present in more than half of isolated hypodontia cases. J Med Genet 49:327-331

van der Hout AH, Oudesluijs GG, Venema A, Verheij JB, Mol BG, Rump P, Brunner HG, Vos YJ, van Essen AJ (2008) Mutation screening of the Ectodysplasin-A receptor gene EDAR in hypohidrotic ectodermal dysplasia. Eur J Hum Genet 16:673-679

Wang Y, Kong H, Mues G, D’Souza R (2011) Msx1 mutations: how do they cause tooth agenesis? J Dent Res 90:311-316

Wisniewski SA, Trzeciak WH (2012a) A new mutation resulting in the truncation of the TRAF6-interacting domain of XEDAR: a possible novel cause of hypohidrotic ectodermal dysplasia. J Med Genet 49: 499-501

Wisniewski SA, Trzeciak WH (2012b) A rare heterozygous TRAF6 variant is associated with hypohidrotic ectodermal dysplasia. Br J Dermatol 166:1353-1356

Wisniewski SA, Kobielak A, Trzeciak WH, Kobielak K (2002) Recent advances in understanding of the molecular basis of anhidrotic ectodermal dysplasia: discovery of a ligand, ectodysplasin A and its two receptors. J Appl Genet 43:97-107

Yamaoka S, Courtois G, Bessia C, Whiteside ST, Weil R, Agou F, Kirk HE, Kay RJ, Israel A (1998) Complementation cloning of NEMO, a component of the IkappaB kinase complex essential for NF-kappaB activation. Cell 93:1231-1240

Yan M, Wang LC, Hymowitz SG, Schilbach S, Lee J, Goddard A, de Vos AM, Gao WQ, Dixit VM (2000) Two-amino acid molecular switch in an epithelial morphogen that regulates binding to two distinct receptors. Science 290:523-527

Yan M, Zhang Z, Brady JR, Schilbach S, Fairbrother WJ, Dixit VM (2002) Identification of a novel death domain-containing adaptor molecule for ectodysplasin-A receptor that is mutated in crinkled mice. Curr Biol 12:409-413

Yin W, Bian Z (2015). The Gene Network Underlying Hypodontia. J Dent Res

Yin Q, Lin SC, Lamothe B, Lu M, Lo YC, Hura G, Zheng L, Rich RL, Campos AD, Myszka DG, Lenardo MJ, Darnay BG, Wu H (2009) E2 interaction and dimerization in the crystal structure of TRAF6. Nat Struct Mol Biol 16:658-666

Yoshida H, Jono H, Kai H, Li JD (2005) The tumor suppressor cylindromatosis (CYLD) acts as a negative regulator for toll-like receptor 2 signaling via negative cross-talk with TRAF6 AND TRAF7. J Biol Chem 280:41111-41121 